\title{
New Adventures of Old Pauline Law
}

Tawia Baidoe Ansah

Florida International University College of Law, tansah@fiu.edu

Follow this and additional works at: https://ecollections.law.fiu.edu/faculty_publications

Part of the Law and Philosophy Commons, and the Religion Law Commons

\section{Recommended Citation}

Tawia Baidoe Ansah, New Adventures of Old Pauline Law , 18 Griffith L. Rev. 385 (2009).

Available at: https://ecollections.law.fiu.edu/faculty_publications/102 
New Adventures of Old Pauline Law

Tawia Ansah

\section{Synopsis}

This article examines the idea of law within two recent philosophical approaches to a theological text. Giorgio Agamben and Alain Badiou, two postmodern philosophers on the political left, look to the letters of St. Paul for the definition and extraction of the political subject. They look to Paul's messianism and his conversion to discover, within their own philosophical projects, what is truly political within the Western philosophical tradition, for which Paul's theology is foundational. The article focuses on the conception of law that, in turn, derives from these projects. The article suggests that within both, despite the objective rejection of positive law, a formalist conception of law returns as the necessary passage between the theological context and the political subject. The article concludes with a discussion of the risks, for the political subject, of the return of this idea of law as the passage to the subject's political realisation.

\section{Introduction}

Postmodern thinkers in the West have long been interested in the intersection of theology and law, particularly as it implicates justice. As Hannah Arendt has noted, 'The first essential step on the road to total domination is to kill the juridical person in man'. ${ }^{1}$ At one level, this corroborates the view of Thomas of Aquinas, that 'Law is the form that providence takes in relation to a free being; the law is to the rational creature what instinct is to the irrational one'. ${ }^{2}$ Aquinas, according to Rémi Brague, 'defines law as the way we act when in full possession of our freedom'. ${ }^{3}$

Giorgio Agamben and Alain Badiou, in their recent writings on St. Paul, raise again the questions of tradition, faith, God, and justice that have been a concern of postmodern thinkers, such as Jean-Luc Nancy in 'Of divine places', ${ }^{4}$ and Jacques Derrida

${ }^{5}$ Tawia Ansah, LL.B., Ph.D., is a professor of law at New England Law $\mid$ Boston.

${ }^{1}$ Arendt (1951), p. 92.

${ }^{2}$ Brague (2007), p. 211.

${ }^{3}$ Brague (2007), p. 223.

${ }^{4}$ Nancy (1991). 
in, for instance, the famous essay, 'Force of Law: The "Mystical Foundation of Authority". 5 But rather than emphasizing the religious or theological element of law even as they undertake a philosophical intervention on theology's terms, Agamben and Badiou present a 'return' to religion in order to extract a politically militant subjectivity in the letters and the figure of Paul. In their quite different approaches to Paul, law is conceptualized as a passage between the religious substrate, the 'particular' context, and the universality of the subject of justice.

For both philosophical approaches, Paul represents the possibility of an immediate relationship to the truth, or to justice. Access to this philosophical 'truth' about the subject is the basis for political action. As such, whatever mediates that relationship - tradition, positive law, theology - must be abandoned, separated from the individual's access to becoming a subject (often referred to as subjectivation, or subjectformation). This would suggest that both philosophical approaches to Paul replicate the antinomian relationship to tradition that seems evident within the letters of Paul. This article will suggest that, on the contrary, whilst law as tradition may be seen to be repudiated on the one hand, law as passage to subjectivation on the other is implicitly prescribed. In short, both approaches require the law in some form - and both reassert law in the most formal terms - in order to achieve the subject. The risk of the reassertion of law as passage is the return of the specific substrate, whether of positive law in its oppressive mode, or of religion as the re-mysitification of the universal index of justice.

Agamben and Badiou perform, through Paul, a relationship to tradition that Paul himself performs, and through this sequence one obtains the formal parameters of the passage - ie law itself - between tradition and the subject. The subject is juridical in the

${ }^{5}$ Derrida (2002). 
sense that it is constituted by the passage, even as the subject is 'subtracted' from all objective relations as such. ${ }^{6}$

This article, then, explores how the philosophers perform this procedure: the risk of the political act as conceptualized through a formal and an aesthetic idea, or ideal, of law as passage to subjectivity. The question posed is: what kind of political action is imagined that requires an idea of law that passes through Paul and the messianic tradition? What happens to the substrate in the wake of the subject's acclimation of a militant (for Badiou) or originary (for Agamben) truth? Pauline messianism is itself both militant and originary, new and traditional. It is continuous with an ancient redemptive promise and, paradoxically, a rupture with the past (for Paul, the traditions of Judaic law and Greek philosophy). In that sense, messianism resembles more recent liberation movements, such as anti-imperialism. The discussion of Paul in relation to Agamben and Badiou ends with a story of a revolt told by Chinua Achebe in his 1959 novel, Things Fall Apart. The story suggests the risk, to the subject, of the political act as a break from law (custom), as itself a 'juridical' passage, and as the space into which positive law in its oppressive form reasserts itself.

Despite the very different outcomes of the philosophers' encounters with theology - for Badiou, law is formalized and tradition 'traversed' in order to yield the universal subject; for Agamben, law is aestheticised and tradition 'fulfilled' in order to yield the messianic subject - both underscore the need to look at thought, ie to apprehend tradition im-mediately, as prerequisite to engagement in the contemporary legal-political project.

\footnotetext{
${ }^{6}$ Hallward (2003), p. xxxiii: 'Rather than seek to transform relations, to convert oppressive relations into liberating relations, Badiou seeks subtraction from the relational tout court. So long as it works within the element of this subtraction, Badiou's philosophy forever risks its restriction to the empty realm of prescription pure and simple'.
} 
There is a risk for the subject in that procedure, as with any system of thought that excludes the very source of its inspiration: the subjective effect of the haunt of ontotheology to thought.

The article suggests that both writers perform something useful for legal theory and progressive thought on the law: through the formal and aesthetic schemas of their own encounters with the Pauline tradition, which in turn replicate Paul's struggle with his own, the writers clarify a recursive gesture within our own relationship to law and our investments in its redemptive capacities. We get to see the limits of the militantprogressive impulse in relation to the construction of the subject, and so we can think through the implications - violent, salvific, redemptive, and formal - of our own political and legal projects.

\section{A. Agamben: Law as Image}

What makes Paul a figure for the philosophical and, I argue, juridical project? Why Paul, as the site of struggle? For Agamben, Paul represents a tradition to be restored in order to access the political. For Badiou, Paul represents the break from tradition in order to access the political. Each will therefore see Paul and his own struggles with tradition through different lenses: did Paul break with Old Law or did he fulfill it? What was Paul's own relationship to law?

Agamben's enterprise in relation to Paul is restorative. He emphasizes continuities rather than breaks within that restored tradition. And the tradition is seen imagistically, as a series of forms. In the Acknowledgements to his monograph on Paul, 
he notes that, 'The ideas in this book developed over a series of seminars" ${ }^{17}$ at various European and US universities in the 1990s. 'The form of the leading idea remained constant throughout each seminar: it always consisted in a commentary ad litteram, in every sense of the word, on the first ten words of the first verse of the Letter to the Romans' ${ }^{8}$ And at the beginning of the text, he states his purpose: 'First and foremost, this seminar proposes to restore Paul's Letters to the status of the fundamental messianic text for the Western tradition'. ${ }^{9}$ The question will be how this view of tradition - as in need of restoration and onto-theological repair; as a formal, constant idea - will inform his analysis of Pauline law and his conception of law as such.

Although the work is structured around the first ten words within Paul's letter to the Romans, Agamben makes much of another passage, 1 Corinthians 29, and the concept of 'as not,' or 'hōs $m \bar{e}$,' in the Greek. This concept seems to encapsulate the relationship between Paul and law, on the one hand, and the Pauline tradition and current practice on the other. It defines the messianic, and thus its interpretation is the vehicle for Agamben's restorative enterprise within the 'incipit', or preamble, to the Romans.

Agamben notes that:

Our hypothesis...presupposes that each word of the incipit contracts within itself the complete text of the Letter [to the Romans], in a vertiginous recapitulation. (Recapitulation is an essential term for the vocabulary of messianism, as we shall see later.) Understanding the incipit therefore entails an eventual understanding of the text as a whole. ${ }^{10}$

\footnotetext{
${ }^{7}$ Agamben (2005a), p. ix.

${ }^{8}$ Agamben (2005a), p. ix.

${ }^{9}$ Agamben (2005a), p. 1.

${ }^{10}$ Agamben (2005a), p. 6 (emphasis in original).
} 
He quotes the ten words, in Greek: 'Paulos doulos christou Iēsou, klètos apostolos aphōrismenos eis euaggelion theou.' Appearing to break with tradition, instead of translating 'doulos' as 'servant of Jesus Christ', he opts for what he calls a 'different scansion': 'Paul, called as slave of Jesus the Messiah, separated as apostle for the announcement of God'. ${ }^{11}$ This scansion as an ex post recapitulation can be linked, analytically and poetically, to the $h \bar{o} s m \bar{e}$ as an a priori, or inherent (ontological), return: of Paul to Moses (after the conversion), of Walter Benjamin to Paul in his later writings, and of Agamben to Benjamin at the conclusion of his scansion of Paul. Each scansion is a fulfillment of sorts, as I hope to show.

The contextual issue, within which the hōs $m \bar{e}$ passage is embedded, has to do with marriage: should one marry, or should one remain celibate ${ }^{12}$ Paul seems to privilege one over the other (he ends up, in 1 Corinthians 40, expressing an opinion favoring celibacy, but notes that it is only his 'judgment', adding coyly, 'and I think also that I have the Spirit of God'); but in the end a hierarchy as such does not really matter, or is rendered inoperative. The question of marriage follows a reflection on the nature of tradition and one's duty to it:

Is any man called being circumcised? Let him not become uncircumcised. Is any called in uncircumcision? Let him not be circumcised. Circumcision is nothing, and uncircumcision is nothing, but the keeping of the commandments of God. Let every man abide in the same calling [klēsis] wherein he was called. Art thou called being a servant [doulos]? Care not for it: but if thou mayest be made free,

\footnotetext{
${ }^{11}$ Agamben (2005a), p. 7.

${ }^{12} 1$ Corinthians $25-40$ (The King James Version).
} 
use it rather. For he that is called in the Lord, being a servant, is the Lord's freeman: likewise also he that is called being free, is Christ's servant [doulos]. This discussion on tradition then ends with: 'Brethren, let every man, wherein he is called, therein abide with God' (1 Corinthians, 18-24).

Paul then faces the fraught question of whether one should marry or remain a virgin (1 Corinthians, 25-40); here, he embeds the essence of the messianic turn, through the hōs $m \bar{e}$ :

But this I say, brethren, the time is short: it remaineth, that both they that have wives be as though they had none. And they that weep, as though they wept not; and they that rejoice, as though they rejoiced not; and they that buy, as though they possessed not. And they that use this world, as not abusing it: for the fashion of this world passeth away (1 Corinthians, 29-31).

The restoration-recapitulation of the messianic as 'fundamental' is thus embedded within the everyday practices of worship, faith, custom, and fidelity to tradition. It is rooted within a temporal view of that everyday-ness of fidelity as extremely compressed. What is restored, then, is not seen as something prior (ie tradition) that 'returns', like a repressed memory of trauma, but something immanent, recapitulative in both senses, ie 'da capo', from the top, as well as a re-capping, a continual process of losing one's head (acephalous) and regaining it, in the instant. Messianic time is ad literatim truncated, suspended. It is an urgent time, a time to be and to act in the now ('ho nyn kairos, the time of the now'). ${ }^{13}$

Messianic time is urgent: being there, within it, and living out its urgency and its distortions, its irreducibility to one or the other 'thing' or state (circumcision or

\footnotetext{
${ }^{13}$ Agamben (2005a), p. 2.
} 
uncircumcision; marriage or celibacy, Jew or Gentile). Thus, tradition is not so much an event that happened in the past, but that which constitutes and (re)iterates one's being in the now.

Inasmuch as the tradition includes positive law, ie law as a series of legal injunctions and proscriptions, it seems clear that for Agamben, the messianic subject is onto-theologically a juridical being. The $h \overline{o s} m \bar{e}-$ or living in the 'as not' - seems to represent not a transcendence of law but its repair: 'In the as not, in a characteristic gesture, Paul pushes an almost exclusively juridical regulation to its extreme, turning it against the law'. As such, Agamben asks:

What does it actually mean to remain a slave in the form of the as not? Here the juridical-factical condition invested by the messianic vocation is not negated with regard to juridical consequences that would in turn validate a different or even opposite legal effect in its place, as does the fictio legis. Rather, in the as not, the juridical-factical condition is taken up again and is transposed, while remaining juridically unchanged, to a zone that is neither factual nor juridical, but is subtracted from the law and remains as a place of pure praxis, of simple 'use' ('use it rather!'). ${ }^{14}$

Within that repair, which requires the law to be itself and unchanged, at once both excessive and inoperative, ${ }^{15}$ is an embedded vector of political potentiality - the form of

\footnotetext{
${ }^{14}$ Agamben (2005a), p. 28 (italics in original).

${ }^{15}$ Agamben (2005a), pp. 28-29: 'Factical klèsis, set in relation to itself via the messianic vocatin, is not replaced by something else, but rendered inoperative....In this fashion, klessis is laid open to its true use. This is the reason that the slave, as defined by Paul, is invested with a messianic vocation through the extraordinary hapax: hyper doulos, "super-slave, slave to the second power"'.
} 
a 'messianic community' to come ${ }^{16}$ as Agamben puts it - precisely within this restorative juridical-subjective project as a kind of overdetermned stasis.

The project is iconistic that is, its central formalist abstraction seems to calibrate a certain iconography (literally, image-writing) and even to hint at iconolatry. Agamben repudiates the new, and his conception of law is ontological, ie, its trajectory is continuous in a synchronic rather than a linear sense. Indeed, it is less a division than a 'cut' between Jew and non-Jew that leads to the formulation of the non-non-Jew, an endless 'Apelles' cut' that lends itself to the circularity of and within the as not, leading to the 'Just One' (just one) of Paul's conversion-call (Acts, 22:14).

The theme of a visual articulation, so to speak, of the subject as a cut (one line) is carried over from his study of Paul to his analysis of 'the open', a concept from Heidegger that delineates the caesura between man and animal (what makes humans beings?), such as in the following passage:

[I]n our culture man has always been the result of a simultaneous division and articulation of the animal and the human, in which one of the two terms of the operation was also what was at stake in it. To render inoperative the machine that governs our conception of man will therefore mean no longer to seek new - more effective or more authentic - articulations, but rather to show the central emptiness, the hiatus that - within man - separates man and animal, and to risk

\footnotetext{
${ }^{16}$ Agamben (2005a), p. 2. This is not a utopian idea: 'To be messianic, to live in the Messiah, signifies the expropriation of each and every juridical-factical property (circumcised/uncircumcised; free/slave; man/woman) under the form of the as not. This expropriation does not, however, found a new identity; the 'new creature' is none other than the use and messianic vocation of the old ( 2 Cor. 5:17: "So if anyone is in the Messiah, the new creature [kaine ktisis]: everything old has passed away; see, everything has become new")', pp. 26-27.
} 
ourselves in this emptiness: the suspension of the suspension, Shabbat of both animal and man. ${ }^{17}$

The emphasis here, as commentators have noted, ${ }^{18}$ is on a kind of subjective passivity, the 'risk' of letting oneself 'be' within the now. Agamben seems to suggest that this is the end result of a process of thought that taps into deep, latent structures, makes them visible, and puts them to use: the subject 'stands serenely in relation with its own concealedness; it lets it be outside of being, ${ }^{19}$ Both as a relation between subject and latency, and in its religiosity and passivity, Agamben's derivation of a subject from his analysis of the Pauline tradition is quite different from that of Badiou. That is, the 'cut' in Agamben is in circular relation to the law; for Badiou, the event is a rupture. In Agamben, the law 'turns' as immanent; in Badiou, it returns as passage.

The messianic subject as a 'remnant' of the cut is visualized or, more precisely, iconized, in two ways: according to a Christian iconography, and according to the abject figure of the Muselmann ('Muslim') of the camps. ${ }^{20}$ Thus, the iconization of the as not seems to relate back to Agamben's so-called 'homo sacer project', ${ }^{21}$ and forward to the

\footnotetext{
${ }^{17}$ Agamben (2003), p. 92.

${ }^{18}$ Hallward (2003), p. 19 on the difference between Heidegger and Badiou: 'There is no conviction more antithetical to Badiou than Heidegger's insistence that "truth is the truth of Being"'.

${ }^{19}$ Agamben (2004), p. 91: 'Thus, the supreme category of Heidegger's ontology is stated: letting be. In this project, man makes himself free for the possible, and in delivering himself over to it, lets the world and beings be as such'.

${ }^{20}$ Agamben (2002), p. 47: 'As suggested by [Primo Levi's] ironically rhetorical Italian title Se questo è un uomo (literally 'If This Is a Man,' translated as Survival in Auschwitz in English), in Auschwitz ethics begins precisely at the point where the Muselmann, the 'complete witness,' makes it forever impossible to distinguish between man and non-man'.

${ }^{21}$ Thomas Carl Wall has described the homo sacer project as follows: 'The theses in Giorgio Agamben in his still expanding Homo Sacer project are, in part: (1) the original political "element" is sacred life; (2) this sacred life, at one time defined as exceptional and excluded from public life, is now virtually coextensive with the political as a whole; (3) as such, as virtually coextensive with the entirety of the political, this sacred life is also virtually banalized (as in the banal expression "politics as usual"); and thus (4) it is the goal of sovereign power, in accord with the logic of the ban, to isolate and to actualize sacred life as banal in conformity to its classical
} 
Christian iconography of his response to Heidegger in The Open: Man and Animal. The icon reiterates the sense of a fusion of elements and their constant division/cut; the effect is a conception of the law as (and as not) law 'all the way down'.

It is a formalist idea and image of law. The formation is already evident in his discovery of Paul at the center of Walter Benjamin's conception of messianism. Benjamin's last works, which Agamben defines as 'a kind of testamentary compendium of his messianic conception of history' are concerned with 'one of the most enigmatic concepts in [his] later thought...the Bild, or image. It appears several times in the text of the Theses, ${ }^{22}$ The image is "“dialectical, in leaps and bounds". ${ }^{23}$ Agamben continues:

Bild thus encompasses, for Benjamin, all things (meaning all objects, works of art, texts, records, documents) wherein an instant of the past and an instant of the present are united in a constellation where the present is able to recognize the meaning of the past and the present therein finds its meaning and fulfillment. We already found a similar constellation in Paul between past and future in terms of what we called a 'typological relation'.

Thus, 'in the Pauline letters the concepts of typos and anakephalaiosis, recapitulation, are tightly intertwined, together defining messianic time'. ${ }^{24}$

The next move is to link, as palimpsest, Agamben himself to Benjamin and then to Paul; this gesture, defined by the image, passes through a Christological/agnostic iconography, as in the following: first, Agamben reiterates both 'a textual

definition as that life which can be killed but not sacrificed. Insofar as it is worthless, utterly banal, this life - nothing but bare life, or life purely insofar as it is political - falls outside any but legal language. There is nothing much to say about this bare life. (I am able-to-be-killed. So what?)'. Wall (2005), p. 31.

${ }^{22}$ Agamben (2005a), p. 141.

${ }^{23}$ Agamben (2005a), p. 141.

${ }^{24}$ Agamben (2005a), p. 142. 
correspondence, and not merely conceptual correspondence, between the theses [of Benjamin] and the letters [of Paul]'. ${ }^{25}$ Next, the link is salvific: 'It will not come as a surprise then that the term redemption (Erlösung) - an absolutely critical concept in Benjamin's notion of historical knowledge - is the term that Luther uses to convey Pauline apolytrōsis, just as crucial to the Letters' ${ }^{26}$ Third, the structure is juridical: 'Whether this Pauline notion is Hellenistic in its origin (from the divine deliverance of the slaves, according to Deissmann), or strictly juridical, or the two together (which is most likely), in any case this orientation toward the past characteristic of Benjamin's messianism finds its canonic moment in Paul'. ${ }^{27}$ The term 'apolytrōsis' links the discussion of Benjamin here to Agamben's address to Heidegger in The Open, where the invocation of the 'mandylion' 28 indirectly recalls the ritual of initiation into a Gnostic cult, reinforcing the view of redemption possible only in a state of 'agnoia' (a kind of emptiness or openness). ${ }^{29}$

The main point here is that an iconic formulation of law has specific utility for Agamben, which is of a piece with his larger philosophical project; one could even say that he literally adopts the Pauline injunction to 'use it rather!' Thus, although Paul is fundamental to him as a philosophical, rather than a theological or even juridical, problem, the law is the turn - the process - through which that problem is 'seen'.

\footnotetext{
${ }^{25}$ Agamben (2005a), p. 144.

${ }^{26}$ Agamben (2005a), p. 144 (emphases in original).

${ }^{27}$ Agamben (2005a), p. 144.

${ }^{28}$ Agamben (2004), p. 92: 'And if one day, according to a now-classic image, the 'face in the sand' that the sciences of man have formed on the shore of our history should finally be erased what will appear in its place will not be a new mandylion or "Veronica" of a regained humanity or animality. The righteous with animal heads in the miniature in the Ambrosian do not represent a new declension of the man-animal relation so much as a figure of the "great ignorance" [agnoia] which lets both of them be outside of being, saved precisely in their being unsavable' (italics in original).

${ }^{29}$ Agamben (2004), p. 91.
} 
Finally, then, the iconism links the Pauline interpretation to Agamben's own homo sacer project which is nothing if not the global juridical subject in a state of crisis: Whatever the case may be, there is no reason to doubt that these two fundamental messianic texts of our tradition, separated by almost two thousand years, both written in a situation of radical crisis, form a constellation whose time of legibility has finally come today, for reasons that invite further reflection. ${ }^{30}$

His reading of Benjamin, which is a restorative reading of Paul within Benjamin, and a restorative messianism within Paul as the 'fundamental' text of Western thought, is the fulfillment of history even as his subject is the legibility of the icon within the now. Nothing new ensues, for, quoting Benjamin (and concluding therewith his discussion of Paul), he affirms that:

'[I]mage is that wherein what has been comes together in a flash with the now to form a constellation. In other words: image is dialectics at a standstill...The image that is read - which is to say, the image in the now of its recognisability bears to the highest degree the imprint of the perilous critical moment on which all reading is founded' ${ }^{31}$

Agamben's formalistic view of law is, at one level, similar to Badiou's, as explained further in the next part. That is, both see the legal category in relation to the subject in formal terms. But there the similarity ends. The iconism of Agamben's form must then play a specific role beyond mere formalism. Iconism enables Agamben to use Pauline law to apprehend modern law, in relation to tradition, in particular interested ways: law, seen as messianic, is restorative. Law is the aesthetic passage to the Pauline

\footnotetext{
${ }^{30}$ Agamben (2005a), p. 145.

${ }^{31}$ Agamben (2005a), p. 145 (citation to Benjamin omitted).
} 
letters, restored as the 'fundamental messianic text for the Western tradition'. Law in this formalistic sense vindicates, or legitimizes, Agamben's restorative project. And the law's operative vindication is important for Agamben because of the capacity for redemption: an iconic, triumphant and perdurable 'Veronica ${ }^{32}$ can thereby, with all the weight of tradition behind it, be opposed to the ravaged and abject iconism of the Muselmann.

Agamben invites an apprehension of law (the as not seeming to evolve into more, rather than less, law) as the necessary bulwark against the sovereign decisional fusion of law and exception. Within the latter, the biopolitical sovereign produces bare life as the means of its own legitimacy.

In short, Agamben uses Paul to oppose a 'suspension of law' (state of exception) with a 'suspension of the suspension.' The suspension of law is detailed within the homo sacer project (the exception produces the homo sacer, or 'bare life'). ${ }^{33}$ The suspension of the suspension, or the as not, is represented by the "now-classic image, the "face in the sand" that the sciences of man have formed on the shore of our history, ${ }^{34}$ an image under erasure. Tradition (represented by Paul) as immanent to law puts its foot (or face) here in the now, in an attempt to staunch the increasing immanence of the camp as global nomos. What is the risk of Agamben's conception of law through this scansion of Pauline messianism? What happens, in other words, when we 'risk ourselves in this emptiness' of a formalist ideal of law? If a break with tradition/law is the evil to be prevented or

\footnotetext{
${ }^{32}$ Agamben (2004), p. 92. The 'Veronica' is the woman at the crucifixion who allegedly wiped Jesus' face. The Latin meaning of the name is 'true icon, bearer of victory.' Here as else, Agamben deploys a thick use of images and icons.

${ }^{33}$ Examples of 'bare life' within Agamben's homo sacer project, include: refugees, internally displaced persons, detainees at Guantanamo Bay, overcomatose patients such as Kathleen Quinlan and Terry Schiavo, and passengers trapped within zones d'atteintes at airports. See also Agamben (2004), pp. 37-38.

${ }^{34}$ Agamben (2004), p. 92.
} 
warded against, then one risk is that continuity itself may elide or suppress such a break. The empty equilibrium of the as not, even as it permits us to see law as non-law - ie, as face to face with itself as law - also risks occluding the political, theological, or other investments on either side of the juridical scale. On the other hand, the messianic subject is the process: ie, its 'legibility' inheres within the meaning of the scansion of Paul, and Paul's of the tradition through which to read Benjamin's suspension. Reading Paul as modern legal thought is a political act. Thus, the subject inhabits the promise of redemption from and within the now, a promise that is also procedural.

How does this conception, and this risk that is law, differ from that offered by Badiou? Both, as noted, conceptualize law in formalistic terms, but where Agamben sees continuity, Badiou sees breaks and ruptures; where Agamben recuperates an ontology, Badiou imagines a miraculous new. And where Agamben conceptualizes the messianic and juridical subject, Badiou, as the following outlines, sees a subject that is universal and translegal. Agamben invites us to inhabit the 'emptiness' of law; Badiou urges redemption ostensibly through political revolt. Agamben's law is subject to interpretation, and Badiou's is subject to truth. Meanwhile, Achebe's story (in the Conclusion) will suggest that whilst in each philosophical project the law as such is not the main protagonist, its return (or turn) carries the risk of a recursive or discretionary violence within the projected state of grace.

\section{B. Badiou: Law as Event}

In the Pauline conversion narrative, we see traditional tropes and symbolic elements. The context within which Paul's conversion is embedded also identifies its symbolic status 
and its struggle with tradition, ie, its break and its continuity with it. In this section, I trace Paul's conversion as a contention with the law, and compare it to Badiou's identification of the conversion as an 'event' that gives birth to the subject. Badiou's identification involves a kind of juridical procedure that resembles Paul's own struggle with the law.

The Bible tells the story of St. Stephen being stoned to death at the gates of Jerusalem as the last event to take place before Saul, as Paul then was, took his journey to Damascus. Saul witnessed the event, but was apparently unmoved. As the story goes, St. Stephen defends himself before the mob by relating the history of the Israelites from Abraham to Solomon (Acts, 7:2-52). He ends by hinting that he, like the prophets of old and like John the Baptist, precedes the 'Just One', and that they, like their forefathers, will 'persecute' him. He also notes that they have 'received the law by the disposition of angels, and have not kept it' (Acts, 7:53). The rabble is incensed and stones him. The narrator then notes that Saul, who consents to the stoning, continued to make 'havock [sic] of the church, entering into every house, and haling [sic] men and women committed them to prison' (Acts $\left.{ }_{2} 8: 1-3\right)$.

Saul is following positive Roman law to the letter, but has also been 'taught according to the perfect manner of the law of the fathers, and was zealous toward God, as ye all are this day' (Acts $22: 3$ ). So the story of Saul's conversion to Paul is also one of transformation of his relationship to the law of the fathers, received from the angels. Like the stoning of St. Stephen, the conversion is also full of symbolic repetitions and resonances that highlight the formal framework at play, both for Paul himself and for what becomes, of this experience on the road to Damascus, a 'tradition' and a trope in its 
own right. Badiou himself, at one point, states that for him, "“I admit without any reticence that May 68 was for me, in the order of philosophy as in everything else, a genuine road-to-Damascus experience", 35 That is, Damascus is an 'event' in the philosophical sense.

Saul's experience is well familiar: 'And as he journeyed, he came near Damascus: and suddenly there shined round about him a light from heaven: And he fell to the earth, and heard a voice saying unto him, Saul, Saul, why persecutest thou me? And he said, Who art thou, Lord? And the Lord said, I am Jesus whom thou persecutest: it is hard for thee to kick against the pricks' (Acts 9:3-5). After an exchange, Saul discovers that he is blind, and is led by his men to a man named Ananias, who has already been instructed in a vision to take Saul in despite the latter's 'evil' reputation. In that vision, God tells Ananias why he must attend to Saul: the latter is the vessel to carry God's message to the Gentiles.

As noted, the event on the road includes several symbolic elements. First, Saul is without sight, and fasts for three days (Acts 9:9). This alludes to the death and resurrection of Jesus himself. Second, Ananias's laying of the hands alludes to the original scene in the Garden of Eden, intimating again the significance of Saul's struggle: And Ananias went his way, and entered into the house; and putting his hands on him said, Brother Saul, the Lord, even Jesus, that appeared unto thee in the way as thou camest, hath sent me, that thou mightest receive thy sight, and be filled with the Holy Ghost. And immediately there fell from his eyes as it had been scales: and he received sight forthwith, and arose, and was baptized (Acts ${ }_{2}$ 9: 17-18).

\footnotetext{
${ }^{35}$ Hallward (2003), p. 33 (cited to Badiou, Théorie de la Contradiction, 9).
} 
Third, the image evoked by 'kicking against the pricks': this agrarian reference ${ }^{36}$ suggests that Saul's zealous defense of the law drives a wedge between himself and God, just as the ox's rebellion against the farmer causes the 'prick' or goad to drive further into its flesh. In other words, the image seems contradictory on its face. But this seems precisely the point: Saul is not consciously rebelling, as the ox might be, but unconsciously. His very obedience to law is causing a physical wedge, represented by the stoning of Stephen, as well as a revolt within his own conscience which, unbeknownst to himself (denied, repressed), causes him to suffer: 'it is hard for you', God says.

The meta-narrative references (to positive law, to the site of original sin) suggest the construction of the event as representing a struggle that takes place both elsewhere (within tradition) and within the mind. As with the meaning of the prophetic tradition outlined by St. Stephen at the gate (the relationship of messenger and message), this too is mytho-poiesis rather than history. Paul himself seems to indicate this element of his story later when he speaks of the 'image' evoked through the contention between the 'new' and the 'old' law: he notes, after speaking of his former obedience to (Mosaic) law as 'veiled,' that under the new dispensation (the gospel), that same law stands exposed and revealed, very much as he had stood on the road to Damascus:

But their minds were blinded: for unto this day remaineth the same vail [sic] untaken away in the reading of the old testament; which vail is done away in Christ. But even unto this day, when Moses is read, the vail is upon their heart. Nevertheless when it shall turn to the Lord, the vail shall be taken away. Now the Lord is that Spirit: and where the Spirit of the Lord is, there is liberty. But we all, with open face beholding as in a glass the glory of the Lord, are changed into the

\footnotetext{
${ }^{36}$ See, e.g., http://www.biblequestions.org/Archives/BQAR075.htm, January 21, 2008.
} 
same image from glory to glory, even as by the Spirit of the Lord (2 Corinthians, 14-18).

Here, the salient point is the transformative and restorative power of the image as that which represents, and frees us from, a mediated past. It has required the work of the imagination, a suffering thought that blindly 'kicks against the pricks,' for the traditional law to be transformed and re-presented as an 'open face'.

The open face, or the sense that one enters the realm of unmediated and liberating truth, is central to Badiou's view of Paul's conversion as an event. Badiou's theory of the event holds first that it occurs unexpectedly given its context or 'situation,' but that it is also contingent on the situation. The event is the situation's hidden potential to strip away what is particular (the historical detail, so to speak) and disclose its universal truth. Typical events for Badiou are political revolts, such as the May 1968 protests, the Paris Commune of 1871, the October Revolution, and the Cultural Revolution. Even in failure, they are 'evental' because they produce individuals that become subjects by nominating the events as truth-giving instances, and then become faithful to those truths. The event is truth-producing in a political sense because it breaks from the normative situation (tradition, custom) characterized by oppression and subjugation; the subject is politically free, autonomous and equal. The subject to truth, like Paul, elects to live by conviction to the truth of the event. ${ }^{37}$

For Paul, the event in question is Christ's resurrection. What transforms law for Paul is how he relates to that event. And for both Badiou and Paul, the working-out of positive law, or tradition, within the event will be central to this new conception of law. In the particular case, Badiou looks to Paul and his fidelity to the (or his, for it is

\footnotetext{
${ }^{37}$ See generally, Badiou (2005b); Hallward (2003); Feltham (2008).
} 
immanently subjective) event as a paradigm of the production of the subject; that is, it is the event, the 'it happened', and not tradition, that produces a subject with the capacity to act politically. Already, then, we see rupture with tradition, rather than the continuity with tradition that characterized Pauline law for Agamben (and Mosaic law for Paul).

But although the event is a rupture, it 'works' upon the material situation, including traditional positive law; it is both unexpected and sudden but also contingent. The event is an 'extraction' from the situation; in that sense it is more abstractified and scientistic than it is iconic, as in the case of Agamben's view of law in relation to the subject. Thus, one could say that for Badiou, the break - or the cut - also, at once, represents the event's consummation of its situation. In Paul's case, the situation is the traditional law, so that it is also possible to say that for Badiou, looking at Paul, law 'returns' to the event as truth-producing in the figure of the subject (to truth) by the working-through, the process and the structuring of (the subject's) nomination of the event and subsequent fidelity to its truth.

Paul is a re-presentation of the very figure of the subjective event for Badiou:

For me, Paul is a poet-thinker of the event, as well as one who practices and states the invariant traits of what can be called the militant figure. He brings forth the entirely human connection, whose destiny fascinates me, between the general idea of a rupture, an overturning, and that of a thought-practice that is this rupture's subjective materiality. ${ }^{38}$

Furthermore, Badiou is not really interested in law, Pauline or otherwise, in his study of Paul. Indeed, positive law, along with all the substantive content of the occurrence, is largely irrelevant. Thus Badiou describes the situation as a 'void' from which the evental

${ }^{38}$ Badiou (2003), p. 2. 
truth is extracted. Paul views the situation in the same way, basing his fidelity to the 'truth' of Christ's resurrection and eliminating all else from within the purview of consideration: 'Paul is a distant figure in a threefold sense: his historical site; his role as Church founder; and his provocative centering of thought upon its fabulous element' (ie the resurrection, as Badiou puts it, is the 'element of fabulation [point de fable]' to which Paul 'reduces the Christian narrative, with the strength of one who knows that in holding fast to this point as real, one is unburdened of all the imaginary that surrounds it'). ${ }^{39}$ To that extent Paul, like Badiou, seems antinomian in this material sense.

But law, in a broad sense, seems to return as the structuration of thought, as formal framework facilitating the truth procedure that inheres in the event. Law returns, as it were, as that traversing line, a displacement of thought from within normative discourse. Law returns to enable conviction (to convict), the call to nomination and fidelity; without it, the call within the conversion event would be shapeless. As Badiou notes elsewhere (in an essay comparing philosophy with psychoanalysis):

Political thinking always ruptures with the dominant state of things. In short, it ruptures with the State. And obviously, in order to do such work, one must enter into the situation, one must meet people and enter into discussion with them; one must exit from one's proper place. Political thinking demands a displacement, a journey which is always, dare I say, abnormal...Politics is disinterested, like science. ${ }^{40}$

Law returns in this scientific-formal sense as the structure of the thought.

\footnotetext{
${ }^{39}$ Badiou (2003), pp. 4-5.

${ }^{40}$ Badiou (2005a), pp. 62-63 (emphases in original).
} 
Law in a regulatory sense is also restored by the event, suggesting a close affinity between law and subject (or process and product, respectively): 'our project: to refound a theory of the Subject that subordinates its existence to the aleatory dimension of the event as well as to the pure contingency of multiple-being without sacrificing the theme of freedom... ${ }^{41}$ The event provides the means of purifying the agent as a re-presentation of the universal: this 'fabulous forcing of the real', as Badiou puts it, is designed to mediate the 'restoring of the universal to its pure secularity, here and now'. All religious or theological intimations of the story must be purged; the very truth extracted by Paul from his own 'event' is essentially a fable. The subject to truth is a subject to the purity of form itself: 'a subject without identity and a law without support'. Thus separated and abstractified, the process 'provides the foundation for the possibility of a universal teaching without history itself'. Truth is this process of 'subtracting' from every contingency: 'the communitarian grasp, be it that of a people, a city, an empire, a territory, or a social class. What is true (or just; they are the same in this case) cannot be reduced to an objective aggregate, either by its cause or by its destination, ${ }^{42}$

It is in these deeply implicated ways, then, that the law operates within Badiou's evental schema even as law in the positive sense seems to be expunged by the rupture with tradition. But the sense of rupture is as important as these indirect intimations to define the legal element (as process or passage) in Paul and, as such, in Badiou's own project, to highlight the differences with Agamben, and to account for the risks involved for the projection of political action pursuant to the event. Arguably, the extraction of truth from all contingency, involving as it does the consummation of the situation,

\footnotetext{
${ }^{41}$ Badiou (2003), p. 4.

${ }^{42}$ Badiou (2003), p. 5.
} 
maintains within the structure itself a haunt of that which is separated from the truth.

This may then condition or limit the extent of the political category itself; that is, there is a latency or a haunt of the theological that clings to the subject in the moment of conviction and fidelity, despite the rigorously secular separation, the 'laicization of infinity $^{43}$ that Badiou expresses elsewhere as the aim of subjectivation.

The connection between the situation and the structure of thought links directly to the subject's parameters or limits. The subject, following nomination, attempts - as does Paul - to "separate each truth procedure from the cultural "historicity" wherein opinion presumes to dissolve it'. ${ }^{44}$ Through the singularity of that event as indeed a conversion event, Paul becomes a subject: 'Whenever Paul addresses his writings, he always draws attention to the fact that he has been entitled to speak as a subject. And he became this subject. He became it suddenly, on the road to Damascus'. ${ }^{45}$

The conversion itself is described as 'a thunderbolt, a caesura, and not a dialectical reversal. It was a conscription instituting a new subject: 'By the grace of God I am what I am [eimi hō eimi]' (1 Corinthians, 15: 10). What this absolutely aleatory intervention on the road to Damascus summons is the "I am" as such'. But the limit to the aleatory nature of the event quickly follows:

Clearly, the encounter on the road mimics the founding event. Just as the Resurrection remains totally incalculable and it is from there that one must begin, Paul's faith is that from which he begins as a subject, and nothing leads up to it. The event - 'it happened', purely and simply, in the anonymity of a road - is the

\footnotetext{
${ }^{43}$ Hallward (2003), p. 9. As to the aim of subject-formation, Badiou notes that "'Subjectivation operates in the element of force whereby place...finds itself altered", Hallward (2003), p. 35 (cited to Théorie du sujet, 54, 271).

${ }^{44}$ Badiou (2003), p. 6.

${ }^{45}$ Badiou (2003), p. 17 (emphasis in original).
} 
subjective sign of the event proper that is the Resurrection of Christ. Within Paul himself, it is the (re)surgence [(ré)surrection] of the subject. This is the exemplary matrix of the link between existence and doctrine, for Paul draws from the conditions of his 'conversion' the consequence that one can only begin from faith, from the declaration of faith. The sudden appearance of the Christian subject is unconditioned.

Furthermore, Paul "does not seek "confirmation" for the event that appoints him in his own eyes as an apostle. He leaves this subjective upsurge outside every official seal' ${ }^{46}$

The point here is that even though the event as an 'upsurge' is from nothing ${ }^{47}$ as such, it is also a re-surgence. To the question: what traces, then, are carried over within the evental process of subjectivation? The answer will be: purely formal elements. Thus, the observation: despite the ostensible break with the law as mediation, and despite the insistently antinomian separation of law and grace - indeed, Badiou has a chapter entitled 'Paul against the law' - the process of subjectivation through the resurgence of the subject within the distance of the event is itself a juridical undertaking, formally speaking. Law is the passage between 'surgence' and (re)surgence.

Badiou makes this point clear in the aforementioned chapter. After delineating the 'four concepts coordinating a subject's fundamental choices: pistis (faith) and ergon (work); kharis (grace) and nomos (law)', he notes that:

The subjective path of the flesh ( $\operatorname{sar} x$ ), whose real is death, coordinates the pairing of law and works. While the path of the spirit (pneuma), whose real is

\footnotetext{
${ }^{46}$ Badiou (2003), pp. 17-18.

${ }^{47}$ Hallward (2003), p. 11: 'Like Sartre's subjects, each of Badiou's must begin its subjective life with a solitary decision, made in the absence of clearly established criteria. Every true subjectivation, every genuine freedom from objective determination or re-presentation, must proceed very literally "ex nihilo".
} 
life, coordinates that of grace and faith. Between the two lies the new real object, the evental given, traversing [my emphasis] 'the redemption which is in Christ Jesus', passing through dia tēs apolutrōseōs tēs en Khristōi Iēsou (Romans, 3: 24).

The choice of word, 'apolytrosis' (redemption) highlights the ritualistic and formal nature of the procedure, corroborating Badiou's basic quest for '[a] philosophy which is a rational intertwining of the event and of truth. A philosophy open to chance, but a chance submitted to the law of reason'; that is, 'a philosophy maintaining unconditional principles, unconditional but submitted to a non-ideological law, ${ }^{48}$

In effect, it is law at the purest, formalist level, law as 'the ideal of the matheme', ${ }^{49}$ that governs the new coming into being of the subject. Thus, to the question: 'But why is it necessary to reject law onto the side of death?' Badiou answers: 'Because considered in its particularity, that of the works it prescribes, the law blocks the subjectivation of grace's universal address as pure conviction, or faith. The law "objectifies" salvation and forbids one from relating it to the gratuitousness of the Christevent'. ${ }^{50}$ As such, the event is, by itself, an 'illegal contingency, which causes a multiplicity in excess of itself to come forth and thus allows for the possibility of overstepping finitude, ${ }^{51}$ The evental $1_{22}^{52}$ situation, before subjectivation, is the site of "the excess of grace, thus, of a pure act', ie the resurrection.

\footnotetext{
${ }^{48}$ Badiou (2005a), p. 42.

${ }^{49}$ Badiou (2005a), p. 67.

${ }^{50}$ Badiou (2003), p. 75.

${ }^{51}$ Badiou (2003), p. 81.

52 Hallward (2003), p xvii. Of this word, Hallward notes: 'After some indecision I have had recourse to the rather clumsy neologism "evental" to translate Badiou's use of the word événementiel... To my mind the more natural choice of "eventful"... invites misleading associations (plenitude, bustle, familiarity)'. See also Badiou (2005b), pp. 506-507 (defining 'Event' and 'Evental Site').
} 
In the result, the ostensible antinomianism of Paul and Badiou is the rejection of law on the order of being in order to make way for the process of law on the order of the event. The former is linked to desire and death, subjecting law to the particularity of 'meaning' and 'interpretation'. The latter is linked to the infinite: resurrection, and thus the Pauline experience, is paradigmatic of the law in the latter case, succinctly expressing the experience of the subject's coming into political effect precisely as revolutionary and transgressive of the normative political order. Law thus conceived as transversal enables the truth through its purely formal-mediatory procedure. Like the matheme to which Badiou relates evental truth, law as subjective resurrection 'obeys the ideal of formalization' ${ }^{53}$

Thus, as with Agamben, the question posed to Badiou's conception of law taken through the Pauline tradition is: what are the risks? These might be considered through appraising the critiques of Badiou's hieratic conception of law, one of which cautions that it risks the resurgence of the flesh (death, desire), per Romans 7: 7. The critique here is that within the immediation of the event, the field of the mediate (law, institution, church) that is traversed shadows the subject thereby produced. The abnormality of the event must needs 'return' to normalcy, either by a counter-insurgency of the State (e.g. following the Paris Commune), by cooptation and inner betrayal (the example Badiou provides is that of the saintliness of Paul curdling into a priesthood),${ }^{54}$ or by relapsing

\footnotetext{
${ }^{53}$ Badiou (2005a), p. 67.

${ }^{54}$ Badiou (2003), p. 38-39 (describing Pasolini's script for a never-made film of Saint Paul, based in New York c.1960s): 'The principal aspect in this trajectory gradually becomes that of betrayal, its wellspring being that what Paul creates (the Church, the Organization, the Party) turns against his own inner saintliness', which begs the question: 'How does genuine saintliness (which Pasolini unhesitatingly recognizes in Paul) bear the ordeal of a History that is at once fleeting and monumental, one in which it constitutes an exception rather than an operation? It can only do so by hardening itself, by becoming authoritarian and organized. But that hardness, which is
} 
into a previous - or mere - discourse. ${ }^{55}$ 'That the event is new should never let us forget that it is such only with respect to a determinate situation, wherein it mobilizes the elements of its site'. ${ }^{56}$

Another potential risk to the conception of law that reflects the ideal of the matheme is that the subject cannot defend against the seduction of interpretation (what does it 'mean'?) thereby compromising the claim to truth. Agamben suggests that Badiou entirely omits the messianic foundation of Paul's message, and as such falls prey to the lure of the Statist discourses Badiou allegedly repudiates. ${ }^{57}$ The risk there, then, is also that one is faithful to an event that produces bad law, e.g., Nazism. ${ }^{58}$ Žižek goes further, and asks:

[W]hat if what Badiou calls the Truth-Event is, at its most radical, a purely formal act of decision, not only not based on an actual truth, but ultimately indifferent to the precise status (actual or fictitious) of the Truth-Event it refers to? What if we are dealing here with an inherent key component of the Truth-Event - what if the

supposed to preserve it from all corruption by History, reveals itself to be an essential corruption, that of the saint by the priest. It is the almost necessary movement on an internal betrayal. And this internal betrayal is captured by an external betrayal, so that Paul will be denounced.'

${ }^{55}$ Badiou (2003), p. 53: 'By granting to the fourth discourse (mysticism) no more than a marginal and inactive position, Paul keeps the radical novelty of the Christian declaration from relapsing into the logic of signs and proofs' (ie Judaic and Greek discourses of knowledge).

${ }^{56}$ Badiou (2003), p. 25.

${ }^{57}$ Agamben (2005a), pp. 51-52: 'This is how, in the book just referred to, Badiou is able to think about Paul's universalism as "benevolence with regard to customs and opinions" or as an "indifference that tolerates differences", which then becomes "that which must be traversed in order for universality itself to be constructed" (Badiou, 98-99). Despite the legitimacy of concepts such as "tolerance" or "benevolence", which in the end, pertain to the State's attitude toward religious conflict (one can see here how those who declare their wanting to abolish the state are often unable to liberate themselves from a point of view of the state), these concepts are certainly not messianic'.

${ }^{58}$ Žižek (2000), p. 143: 'From a Hegelian standpoint there is a deep necessity in [determining the question of what is a Truth-Event and what is its "mere semblance"], confirmed by the fact that in our century the philosopher who provided the definitive description of an authentic political act (Heidegger in Being and Time) was seduced by a political act that was undoubtedly a fake, not an actual Truth-Event (Nazism)'. 
true fidelity to the Event is 'dogmatic' in the precise sense of unconditional Faith, of an attitude which does not ask for good reasons and which, for that very reason, cannot be refuted by any 'argumentation'?

Badiou might respond that "not every "novelty" is an event. It must further be the case that what the event calls forth and names is the central void of the situation for which this event is an event. This matter of nomination is essential,' he suggests, and as such, Nazism is in fact the opposite of an event: 'When a radical break in a situation, under names borrowed from real truth-processes, convokes not the void but the "full" particularity or presumed substance of that situation, we are dealing with a simulacrum of truth'. ${ }^{60}$

In the result, Badiou's formula does not depend upon the success of the event in any historical sense, on the contrary: Christ died, Paul was persecuted, the Paris Commune failed, and so on. But each resurrects a prior 'event' precisely as a formal truth, converting and renaming the subject to that truth by an active, ie political, intervention of the subject herself. Thus, Badiou's schema intimates the possibility of law itself as something new; elsewhere, he defines the (re)surrection of the new as a “"space of compossibility" for all contemporary fidelities" ${ }^{61}$ With this in mind, I turn to the story of Achebe's political revolt, in order to assess the risk of the new as a juridical project. That instance too is a failed operation or, as Žižzek might say, a 'nothing really

59 Žižek (2000), p. 144 (emphases in original)

${ }^{60}$ Badiou (2002), p. 73.

${ }^{61}$ Badiou (2005a), p. 25 (emphasis in original). 
happens' event ${ }^{62}$ since, of course ${ }_{2}$ it is only a novel (a fable). But perhaps therein lies its claim to evental truth.

\section{Conclusion}

Both Agamben and Badiou develop philosophical projects that work through the theology of Paul in order to derive a question about political action. Their journeys through Paul have involved an encounter with the law. This article has suggested that the encounters of the philosophers are similar to Paul's struggle with his own tradition, both philosophical and legal. As such, these two postmodern philosophical projects, whilst quite different (some might say opposed in important ways), ${ }^{63}$ are both marked by the Pauline experience in similar ways, not the least in recovering, through Paul, a formalistic conception of law.

The question of what happens, after subjectivation, to the abandoned substrate from which the subject is extracted (for Badiou) or through which the subject is divided (for Agamben) also informs what happens to the law. That is, how is the law shaped as the passage, the 'structure' of thought, on the road to political engagement? To what extent is there a trace of the theological substrate, and a haunt of the sacred, within the passage from encounter to action? And what of the undercurrent of violence that pervades these schemas, given the necessity for a 'suspension' in Agamben and for an

62 Žižek (2000), p. 135: 'The fundamental lesson of postmodernist politics is that there is no Event, that "nothing really happens", that the Truth-Event is a passing, illusory short circuit, a false identification to be dispelled sooner or later by the reassertion of difference or, at best, the fleeting promise of the Redemption-to-come, towards which we have to maintain a proper distance in order to avoid catastrophic "totalitarian" consequences; against this structural skepticism, Badiou is fully justified in insisting that - to use the term with its full theological weight - miracles do happen....'

${ }^{63}$ Hallward (2003), p. 20: Badiou might characterize Agamben's discursive analysis, dependent upon meaning and interpretation, as 'antiphilosophical', against which Badiou's whole philosophical project is opposed. 
evental 'revolt' in Badiou? Paul's militant stand against the Roman Empire is part of the historical substrate, the context within which his messianism and his conversion are antiimperialist revolt and exception to the political norm. Achebe, a Nigerian novelist at the height of pan-African anti-colonialism, writes with a keen ear to historical resonances. His story of a hero - or anti-hero? - of that movement suggests the cultural-critical parallel to the philosophical encounters with Paul, and implicates the political and legal risks involved pursuant to the Pauline trajectory.

Okonkwo, the protagonist of Achebe's novel, Things Fall Apart, embodies and performs both positive law and its rupture within the event. His ultimate act of violence is also an act of grace. It is nostalgic, as a final, doomed attempt to recapitulate a dying tradition; antinomian, as it violates the norms of that tradition and desecrates the land upon which the act takes place; evental, as the 'undecidable' ${ }_{2}$ impossible to have imagined within the context of that African-traditionalist culture and unforeseeable within the situation from which that political act - murder of the District Commissioner's messenger - evolved; and messianic, as a war of redemption on behalf of his people that turns into self-sacrifice. Okonkwo becomes a subject through the event and his fidelity to its own evental truth, but his subjectivation accelerates a resurgence of law (colonial governance) that shapes a new community within which Okonkwo as subject could not have survived.

The end of Achebe's novel is packed with the excitement of its protagonist rising up against the new British authorities (he slays the Commissioner's messenger), but too late. As a suicide, he cannot be touched and buried by his fellow villagers: his political revolt on their behalf has recast heroism to abjection. In a passage thick with dramatic- 
mythical allusions (e.g., Oedipus and Jocasta; Creon and Antigone), Achebe ends the novel with the District Commissioner contemplating Okonkwo's body dangling from a tree:

In the many years in which he had toiled to bring civilization to different parts of Africa he had learned a number of things. One of them was that a District Commissioner must never attend to such undignified details as cutting a hanged man from the tree. Such attention would give the natives a poor opinion of him. In the book which he planned to write he would stress that point. As he walked back to the court he thought about that book. Every day brought him some new material. The story of this man who had killed a messenger and hanged himself would make interesting reading. One could almost write a whole chapter on him. Perhaps not a whole chapter but a reasonable paragraph, at any rate. There was so much else to include, and one must be firm in cutting out details. He had already chosen the title of the book, after much thought: The Pacification of the Primitive Tribes of the Lower Niger. ${ }^{64}$

Achebe skillfully blends a critique not only of the Commissioner, but also of Okonkwo himself. The production of law (norms of colonial practice; disciplinary procedures; etc.) from the Commissioner's pacifying gaze is the Restoration to Okonkwo's Insurgency. The insurgency is 'evental' inasmuch as the subject undertakes the risk of absolute fidelity to its truth.

Okonkwo's suicide is a futile attempt to preserve and extend a culture and a tradition through his willful transgression and the desecration of that very culture. It is an act that is faithful to the murder of the messenger, which itself traverses the norms. The

${ }^{64}$ Achebe (1959), p. 209. 
very futility of the suicide as a political act seems to resonate, in the aftermath, with its capacity to engender a new situation: in the immediate context it permits the return of law (suicidal body as juridical poiesis), the capitulation of the populace expressed in a ritual of purification, the martyrdom of the hero. And within the normative situation, the death of Okonkwo is shameful, a disgrace. Okonkwo cannot yield to the new order, and things fall apart. And so the paradox, for Okonkwo as for any subject of the 'event', is that the conversion moment, the revolt, promises redemption but risks abjection.

Achebe's novel ends in ways that are similar to the Pauline trajectory, after the event: the universal subject is 'resurrected', but so is positive law in its most rigid form. Okonkwo's legacy can be traced, as can Paul's, within the singularity of a universal truth and the law as passage to that truth: fidelity of the subject to the anticolonial evental break, or to the messianic suspension within the subjective division. But the legacy can also be traced within the rise of the Church, and of the neo-colonial State: in the eyes of Okonkwo's friend, also standing by the body, we see the glimmer of an impotent rage and thirst for revenge. Achebe, like the philosophers in their address to Paul, seems to warn of the thin line that separates and implicates these two strains: subjectivation of the universal truth of the political, and the violence of the particular that attends it. 
Reference List:

Alain Badiou (2002) Ethics: An Essay on the Understanding of Evil, Verso.

Alain Badiou (2005a) Infinite Thought, Continuum.

Alain Badiou (2005b) Being and Event, Continuum.

Alain Badiou, (2003) Saint Paul: The Foundation of Universalism, Stanford University Press.

Chinua Achebe (1959) Things Fall Apart, Doubleday.

Giorgio Agamben (2001) Homo Sacer: Sovereign Power and Bare Life, Stanford University Press.

Giorgio Agamben (2002) Remnants of Auschwitz: The Witness and the Archive, Zone Books.

Giorgio Agamben (2004) The Open: Man and Animal, Stanford University Press.

Giorgio Agamben (2005a) The Time That Remains: A Commentary of the Letter to the Romans, Stanford University Press.

Giorgio Agamben (2005b) State of Exception, Chicago University Press.

Hannah Arendt (1951) ‘Total Domination' in N. Jumonville (ed) The New York Intellectuals Reader, Routledge (2007).

Jacques Derrida (2002) 'Force of Law: The 'Mystical Foundation of Authority', in Gil Anidjar (ed) Acts of Religion, Routledge.

Jean-Luc Nancy (1991) 'Des lieux divins' in Peter Connor, Lisa Garbus, Michael Holland, and Simona Sawhney (trans.) The Inoperative Community, Minnesota University Press. 
Oliver Feltham (2008) Alain Badiou: Live Theory, Continuum.

Peter Hallward (2003) Badiou: A Subject to Truth, Minnesota Press.

Rémi Brague (2007) The Law of God: The Philosophical History of an Idea, Chicago University Press.

Slavoj Žižek (2000) The Ticklish Subject: the absent centre of political ontology, Verso.

The Bible. The King James Version of the Bible was originally published in 1611.

Thomas Carl Wall (2005) 'Au Hasard' in A. Norris (ed) Politics, Metaphysics, and

Death: Essays on Giorgio Agamben's Homo Sacer, Duke University Press. 